\title{
Simulation the Probability of Liberalizing Chlorin Gas from Urban Water Chlorination System in Alborz: With the Cancer Approach
}

\author{
Reza Moradi ${ }^{1}$, Ahmad Nikpey $^{2}$, Hamzeh Saeidabadi $^{3}$, Saeed Yari $^{4}$
}

${ }^{1}$ Department of Occupational Health, Alborz Health Center, Qazvin, Iran. ${ }^{2}$ Ph.D. of Occupationa Department of Occupational Health Engineering, Qazvin University of Medical Sciences, Qazvin, Iran. ${ }^{3}$ Islamic Azad University of Tehran, West Tehran Branch, Tehran, Iran. ${ }^{4}$ Student Research Committee, (Department and Faculty of Health), Shahid Beheshti University of Medical Sciences, Tehran, Iran.

\begin{abstract}
Background: Qazvin province has suffered a lot of natural disasters (earthquakes) for a long time. so, the establishment of the first industrial city in Iran, has always been a source of concern. One of these problems is the possibility of chlorine gas leaking from the chlorination system of drinking water and treatment plant the existing ones are on the health of the inhabitants of this region. Material and method: This analytical study was carried out in Novorossiysk district of Alborz in December 2012. Initially, chlorine gas leakage scenarios from these facilities were simulated by ALOHA and WISER software, and then using the Emergency Level System, according to the CCPS Consultative Center's Chemical Process Safety Advice, the Emergency Response Program was presented. Results: ALOHA software, in comparison with WISER software, has more precision to identify and address the consequences of chlorine gas leakage hazards and according to the simulation of this software in the event of a leak from the well and water resources unit at $8240 \mathrm{~m}$ from the area and at night 7520 meters will be affected. Due to the speed of delivering results through the WISER software, this software can be used at times when the operating speed is considered (incident time). Conclusion: According to the CCPS model, the emergency conditions were classified at levels 3 and 4, therefore, the relevant crisis management agencies (Qazvin Crisis Management Committee, Alborz City Health Center, Red Crescent and Firefighting Authority) should provide training maneuvers At Alborz city level, and informing people of cities and industrial companies, many efforts have been made to reduce human and environmental damage in case of possible leakage.
\end{abstract}

Keywords: Chlorine Gas Leakage- ALOHA- WISER- CCP- Cancer

Asian Pac J Environment and Cancer, 2 (1), 17-22

\section{Introduction}

Qazvin province was the capital of Iran during the reign of Shah Tahmasb I and was very prosperous politically, religiously and commercially [1]. The occurrence of very severe earthquakes during the capital of Qazvin was one of the important factors in transferring the capital from Qazvin to Isfahan [2-4]. Regardless, the establishment of industrial units began in the Safavid era, and over time it went through stages of growth. Alborz industrial city started in 1968 as the first industrial city of Iran [5]. According to the Ministry of Industry, the Alborz Industrial City was established in 1347 to implement
Submission Date: 01/11/2019 Acceptance Date: 03/14/2019

decentralization policies for industrial workshops in Tehran and to create new industrial hubs outside the Greater Tehran area [6]. And erected on 900 hectares of Eric, 140 kilometers northwest of Tehran and 15 kilometers southeast of Qazvin.550 acres were allocated to the east, industrial areas (Which holds about 450 manufacturing and industrial units), 112 acres of commercial areas ( 80 hectares to residential areas and 32 hectares to commercial areas, including 394 business units - workshop, more than 603 Commercial - Neighborhood units) and the rest of the land to public roads and facilities. The population of Alborz city according to the 2011 census was 203276 people, which is very important for water supply, industrial

Corresponding Author:

Dr. Hamzeh Saeidabadi

Islamic Azad University of Tehran, West Tehran Branch, Tehran, Iran.

Email: Saeedabadi.h@gmail.com 
and household use. The city has two water drainage units (Wells and Water Resources Unit, which is responsible for supplying potable water in the northwest including telemetric installations for continuous and online control of water pressure and total water consumption, a metallic air source of 2000 cubic meters with a height of 42 meters), the largest refinery in the Middle East, with a capacity of up to 90,000 cubic meters, which is responsible for water supply for agriculture and is located in the southwest of the city [7]. Exposure to chlorine gas at a concentration of 14-21 ppm for half to one hour is dangerous and a concentration of $100 \mathrm{ppm}$ cannot be tolerated for more than one minute [8]. In fact, it is toxic but not carcinogenic $[9,10]$. But Rook discovered that the combination of chlorine with organic compounds in drinking water produced halogenated organic compounds-chloroform [11]. That is a carcinogen [12]. Also Morris suggest a positive association between consumption of chlorination by-products in drinking water and bladder and rectal cancer in humans [13]. under normal conditions, if 10 tons of chlorine is released into the air, it will produce a concentration of $140 \mathrm{ppm}$ within $2 \mathrm{~km}$ of the source and a concentration of about $5 \mathrm{ppm}$ within $5 \mathrm{~km}$. Due to the use of chlorine in urban areas and population density in large cities, the depth of the disaster is clearly evident [14]. Chlorine gas leak from Astara's 50-tonne cylinder kills 40 and injures 200, and the accident of chlorine gas leak at Tehran Water Treatment Plant in December 2001 resulted in the death of 2 people and the injury of 50 people [15]. According to official statistics, production, transportation, consumption and storage of chlorine takes 52 lives daily. Following is a list of a number of chlorine gas events in Iran and around the world.

In a study by Ramabraham and Swaminathan (2000) at a chlorine gas storage facility, after studying the process risks, a general template for an emergency response program was presented that was useful, but general, and Emergency levels for different release scenarios were not specified [16]. Adel et al. (2007) identified the most important factors in the occurrence of chlorine leakage in drinking water chlorination stations using Fault Tree Analysis (FTA) technique, and the most important causes of the chlorine leakage were, low skill level of staff (due to lack of appropriate training courses for relevant personnel), high workload on staff, lack of integrated guidelines and regulations in the chlorination stations, design flaws and the probability of an happening accident 21 times a year (That was a relatively high figure). By modifying the basic concepts or designing the stations, the probability of an accident decreases dramatically on a standard basis [15]. Tsang et al. (2008) examined the different stages of a chlorine gas emergency response program in process plants in Taiwan, but did not use any process risk assessment methods and did not specify release scenarios, also the radius of damage was not specified when released into the environment. In this study, IDLH of chlorine gas considered PPM 30 (Immediately Dangerous to Life or Health Concentration) [17]. Some studies have measured the consequences of environmental toxicity with the criteria of TLV-TWA, ERPG, LD50, TLV-
STEL, PROBIT [18-23]. Mahoney et al. (2008) presented a model for identifying emergency response areas as hot, warm and cold areas with ALOHA (Arial Location of Hazardous Atmospheres) software around the toxic gas emission range based on the Acute Exposure Guideline Levels (AGLEs), but in the study They did not mention the duties of the various groups when emitting toxic gases [24]. Thus, given that a large number of major industrial events in the last century have been related to the release of toxic chlorine gas into the environment [25-26]. People at risk of exposure can include the workers near the leak site and community members who residing adjacent to industrial areas [27]. The main purpose of this study was to describe possible scenarios of chlorine gas leakage from the drainage unit of wells and water resources and treatment plant in Alborz city and its possible effects on urban and industrial areas.

\section{Materials and Methods}

This study was carried out in December, 2016, in the drainage unit of wells and water resources of Alborz city. In the water drainage unit, there are two $800-\mathrm{kg}$ chlorine gas cylinders, which are transported in a supine position and the outputs of these two cylinders are connected to the drainage circuit cylinder. The cylinder was perpendicular to collect the chlorine impurities below the cylinder and to send chlorine gas from the top for chlorination, and the cylinders were kept in a 2-by2-meter room. Room temperature in summer is ambient temperature and in winter use of heating devices to prevent freezing of chlorine gas and an average of 15 days an 800$\mathrm{kg}$ cylinder is used. Due to the importance of chlorine gas in this study, ALOHA and WISER software were used to simulate the potential of chlorine gas leakage. Both of this software are widely used in crisis management and emergency response. Today, many models have been developed for modeling gas emissions and they are developing. These models are presented in software packages using mathematical models, each of them has advantages and disadvantages, the most important of which are ALOHA, PHAST, HGSYSTEM, DEGADIS - SLAB [18-19-22-28-31]. ALOHA software has various features including material database, prediction of concentration at a given location and moment, fire radiation and explosion wave charts, wind speed, geographical conditions, surface roughness, distance and modeling time [32]. It is a powerful computer software that is used to calculate the probable outcome of an accident [33]. WISER (Wireless Information System For Emergency Responders) software is used for hazardous chemical accidents and contains extensive information on hazardous substances, Includes: Identification of 5236 chemicals and 438 matter base on physical and chemical properties, Guidelines for material identification, Physical characteristics, Medical information and Material safety data sheet, also It is generally a reference for rapid modeling in the early minutes of major events and is used in both Android and Windows [34]. The software was used in the explosion of the Canadian Quebec freight train, 
which estimated the effects of the blast on the affected area. The train was carrying crude oil from North Dakota, that departed from the railroad on July 6, 2013 in Lak Magentic, 250 kilometers east of Montreal. this fatal accident killed 47 people and caused hundreds of millions of dollars in damage. This is the biggest rail accident in the last two decades [35]. the emergency response program was developed according to the process safety management system, which has a great importance and advantage in the process industries [36-37]. In this system, emergency levels were defined as recommended by Center for Chemical Process Safety (CCPS). According to the severity of the accident, the extent of the pollution spread and the exposed population in the event, emergency actions were divided into four categories: Emergency Level 1: When hazardous substances exist or likely exist, but there is no leakage, spillage, fire or explosion, and it is not expected to occur. Emergency Level 2: When there are no serious health effects, but release or fires may be diagnosed by people working due to odors or clouds, and the surrounding population may be paying attention and asking questions. Emergency Level 3: When release or potential release is identified as a threat to the health of the surrounding community and is likely to be caused by control measures. At this level, emergency responders will be alerted to take action if necessary. If control is lost, release can become an emergency situation in society, or if the control is successful, the level of emergency can be reduced to level 2. Emergency Level 4: When the happened release can cause adverse effects on the community living around of the industrial area, at this level all emergency responders in the city are aware of the accident and take appropriate action. At this level, appropriate response measures are spread to the surrounding community[38].

\section{Results}

As mentioned, Alborz Industrial City is bounded from the northwest by the drainage unit of wells and water resources and from the southwest by the drainage unit of the sewage treatment plant. Given that the annual wind direction of May wind in Qazvin province from the north and northwest and the secret wind from the south and southeast (wind percentage 7.12 and speed of $4 \mathrm{~m} / \mathrm{s}$ is more intense from mid-spring to late summer) [39]. in

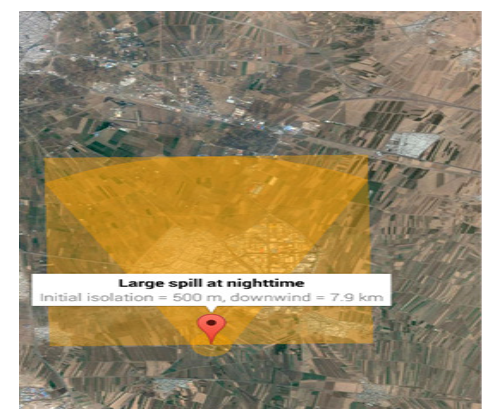

Figure 1. Simulation of Chlorine Gas Leakage from the Treatment Plant Using WISER Software

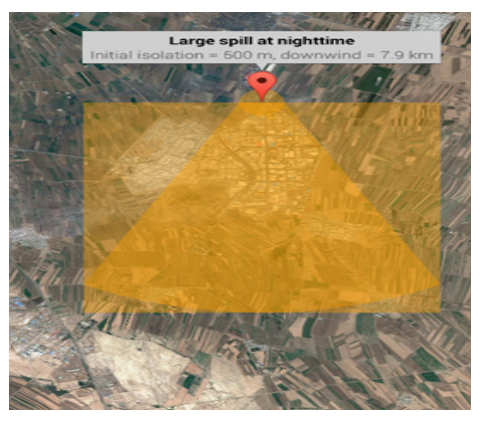

Figure 2. Simulation of Chlorine Gas Leakage from Wells and Water Resources using WISER Software

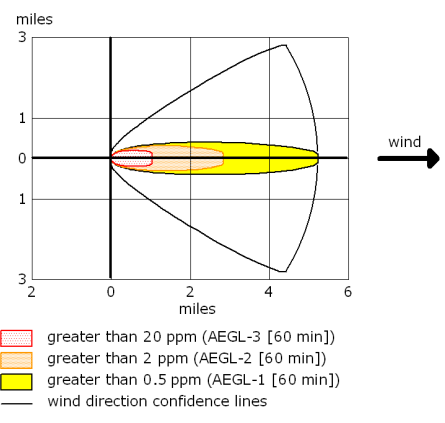

Figure 3. Simulation of High Daily Chlorine Gas Leakage from Wells and Water Resources using ALOHA Software

the two-wind mentioned above, there is more emphasis on the expression of scenarios.

The worst-case scenario provided by WISER software is a leakage from a treatment plant (Figure 1) or wells and water resources (Figure 2), and the direction of the wind to the south and north respectively and the possibility of leakage at night. The following two figure are specified, the Isolate 500 and the Affected Areas are 7900 meters, which confirms the importance of developing and implementing an emergency management plan for all Alborz residents (including Alvand and Nosrat Abad).

\section{Discussion}

\section{Discussion and conclusion}

In general, due to the confinement of Alborz city to both chlorination units and the monsoon winds that cause

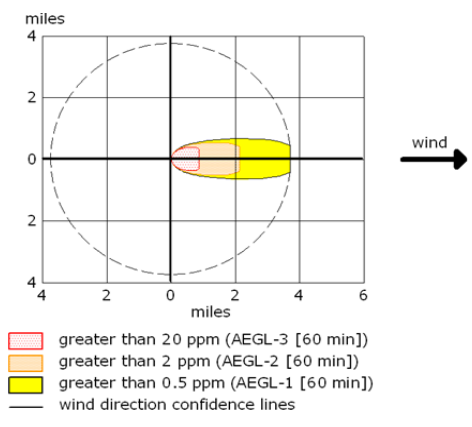

Figure 4. Simulation of High Chlorine Leakage at Night from the Treatment Plant using ALOHA Software 
Table 1. Chlorine Gas Leakage Events in Iran

\begin{tabular}{|c|c|c|c|c|}
\hline Year & Month & City & Cause & Consequences \\
\hline 2004 & October & Iron scrap market, Tehran & Chlorine leak from used capsule & 2 injured \\
\hline 2011 & August & Tehran & Chlorine gas leaks in a pool & 14 injured \\
\hline 2012 & January & Mashhad & Chlorine gas leaks in a pool & 30 schoolgirls poisoned \\
\hline 2012 & February & $\begin{array}{l}\text { Hunan Pool, Sarasiab St, } \\
\text { Tehran }\end{array}$ & Chlorine gas leaks from a capsule & 4 persons with respiratory problems \\
\hline 2012 & July & Elahieh Hotel, Qazvin & Chlorine gas leaks from a capsule & 190 hospitalized \\
\hline 2012 & September & $\begin{array}{l}\text { Paksho Company, Alborz } \\
\text { Industrial City, Qazvin }\end{array}$ & $\begin{array}{l}\text { Combining Sodium hypochlorite with } \\
\text { hydrochloric acid and creating } \\
\text { chlorine gas }\end{array}$ & $\begin{array}{l}7 \text { persons with acute respiratory } \\
\text { problems }\end{array}$ \\
\hline 2012 & December & A swimming pool, Tabriz & Chlorine gas leaks from a capsule & 9 persons with respiratory problems \\
\hline 2013 & December & Eghbaleh, Qazvin & Chlorine gas leaks from a capsule & $\begin{array}{l}6 \text { persons with acute respiratory } \\
\text { problems }\end{array}$ \\
\hline 2015 & September & $\begin{array}{l}\text { Chanan Castle Village, } \\
\text { Khuzestan }\end{array}$ & $\begin{array}{l}\text { Deliberate release of } 100 \mathrm{Kg} \text { capsules } \\
\text { by thieves }\end{array}$ & 100 poisoned \\
\hline 2017 & August & Dezful, Khuzestan & $\begin{array}{l}\text { Chlorine gas leaks from a } 700 \mathrm{Kg} \\
\text { capsule }\end{array}$ & 475 injured \\
\hline
\end{tabular}

Table 2. Chlorine Gas Leakage Events in the World

\begin{tabular}{|c|c|c|c|}
\hline Date & Country & Cause & Consequence \\
\hline April 30, 1974 & Yukaiichi, Japan & Chlorine leak in transit & 521 killed \\
\hline February 22, 1978 & Youngston, USA & Chlorine leak in rail transport & 8 killed, 138 injured \\
\hline August 4, 1981 & Mexico & Accident during chlorine road transport & $\begin{array}{l}28 \text { killed, } 1000 \text { injured and } 5000 \\
\text { drain }\end{array}$ \\
\hline July 7, 1987 & The former Soviet Union & Accident during chlorine transport & 200 injured \\
\hline January 17,1990 & Germany & Release of chlorine from the tanker & More than 182 injured \\
\hline April, 1994 & India & Accident during transport & 1 killed, 150 injured \\
\hline January, 1997 & Pakistan & Accident during transport & $\begin{array}{l}22 \text { killed, } 900 \text { injured and } 1000 \\
\text { drain }\end{array}$ \\
\hline April 16, 2004 & Chin & $\begin{array}{l}\text { Chlorine leakage from chlorination } \\
\text { station }\end{array}$ & $\begin{array}{l}9 \text { killed and evacuated people up } \\
\text { to } 3 \mathrm{~km} \text { radius }\end{array}$ \\
\hline April 30, 2004 & Chin & Chlorine leak & 282 Outpatient Injury, 6 Injury \\
\hline April 11, 1996 & Montana, USA & Chlorine leak & 350 injured \\
\hline March 31, 2005 & Chin & Take the tanker off the rails & 27 killed, 285 injured \\
\hline April 12, 2005 & Chin & Chlorine leak & 88 injured \\
\hline January 6,2005 & USA & Take the tanker off the rails & 8 killed, 260 injured \\
\hline January 13, 2005 & North Carolina, USA & Take the tanker off the rails & 9 killed \\
\hline April 21, 2006 & Chin & Chlorine leak & 22 injured \\
\hline July 10, 2006 & Chin & Chlorine leak & 164 injured \\
\hline September 21, 2007 & Chin & Chlorine leak & 62 injured \\
\hline
\end{tabular}

the possible transfer of chlorine gas leakage to residential areas (Nosrat Abad and Kemalabad and Alborz Industrial City). Emergency situations can be classified into levels 3 and 4 according to the CCPS model. Therefore, the relevant crisis management organizations (Qazvin Governorate Crisis Management Committee, Alborz Health Center, Red Crescent and Fire Department) should make great efforts to conduct educational maneuvers at Alborz city level and to inform the people of industrial cities and companies to reduce the amount of human and environmental damage if the leak occurs. The results of the Shahidi and Motevalian study showed that chlorine gas poisoning induces mitosis of murine white blood cells and in fact can be considered as an effective factor in the proliferation of white blood cells. In other words, although chlorine cannot be categorically identified as a carcinogen, it can at least be regarded as a mitogen, but further research is needed to prove it carcinogenic [40]. In this study, it was found that ALOHA software is more accurate than WISER software for identifying and presenting the consequences of chlorine gas leakage on residential and industrial areas of Alborz city. and by simulating this software, the leakage from the wells and water units will be affected at 8240 meters per day and 
Table 3. Chlorine Gas Leak Simulation with ALOHA and WISER Software

\begin{tabular}{|c|c|c|c|c|c|c|c|c|c|c|}
\hline \multicolumn{2}{|c|}{ Leakage location } & \multirow{3}{*}{$\begin{array}{l}\text { Leakage } \\
\text { Much }\end{array}$} & \multirow{3}{*}{$\begin{array}{l}\text { Time } \\
\text { Day }\end{array}$} & \multirow{3}{*}{$\begin{array}{l}\text { wind direction } \\
\text { North to South }\end{array}$} & \multicolumn{3}{|c|}{ ALOHA } & \multicolumn{2}{|c|}{ WISER } & \multirow[t]{2}{*}{ involved Areas } \\
\hline & & & & & $\begin{array}{c}\text { Hot } \\
\text { (meter) }\end{array}$ & $\begin{array}{l}\text { Warm } \\
\text { (meter) }\end{array}$ & $\begin{array}{c}\text { Cold } \\
\text { (meter) }\end{array}$ & $\begin{array}{l}\text { Isolated area } \\
\quad \text { (meter) }\end{array}$ & $\begin{array}{l}\text { Effective area } \\
\quad \text { (meter) }\end{array}$ & \\
\hline 1 & $\begin{array}{l}\text { Wells and Water } \\
\text { Resources }\end{array}$ & & & & 1600 & 4800 & 8000 & 500 & 3000 & Alborz Industrial City \\
\hline 2 & $\begin{array}{l}\text { Wells and Water } \\
\text { Resources }\end{array}$ & Low & Day & North to South & 1280 & 4000 & 7200 & 60 & 400 & $\begin{array}{l}\text { Companies close to } \\
\text { chlorination }\end{array}$ \\
\hline 3 & $\begin{array}{l}\text { Wells and Water } \\
\text { Resources }\end{array}$ & Much & Night & North to South & 1600 & 4480 & 7520 & 500 & 7900 & Alborz city \\
\hline 4 & $\begin{array}{l}\text { Wells and Water } \\
\text { Resources }\end{array}$ & Low & Night & North to South & 1120 & 3680 & 6880 & 60 & 1500 & $\begin{array}{c}\text { Near Industrial City Square } \\
2\end{array}$ \\
\hline 5 & $\begin{array}{l}\text { Wells and Water } \\
\text { Resources }\end{array}$ & Much & Day & South to North & 1600 & 4800 & 8000 & 500 & 3000 & $\begin{array}{l}\text { At the beginning of the } \\
\text { industrial city road }\end{array}$ \\
\hline 6 & $\begin{array}{l}\text { Wells and Water } \\
\text { Resources }\end{array}$ & Low & Day & South to North & 1280 & 4000 & 7200 & 60 & 400 & Places near the drainage unit \\
\hline 7 & $\begin{array}{l}\text { Wells and Water } \\
\text { Resources }\end{array}$ & Much & Night & South to North & 1600 & 4480 & 7520 & 500 & 7900 & $\begin{array}{c}\text { Municipality } \\
\text { Residential Areas }\end{array}$ \\
\hline 8 & $\begin{array}{l}\text { Wells and Water } \\
\text { Resources }\end{array}$ & Low & Night & South to North & 1120 & 3680 & 6880 & 60 & 1500 & $\begin{array}{l}\text { At the beginning of the } \\
\text { industrial city road }\end{array}$ \\
\hline 9 & treatment plant & Much & Day & North to South & 1440 & 3520 & 6720 & 500 & 3000 & Alborz Industrial City \\
\hline 10 & treatment plant & Low & Day & North to South & 800 & 2400 & 4560 & 60 & 400 & Places near the drainage unit \\
\hline 11 & treatment plant & Much & Night & North to South & 1440 & 3040 & 5440 & 500 & 7900 & Alborz city \\
\hline 12 & treatment plant & Low & Night & North to South & 800 & 2720 & 4800 & 60 & 1500 & $\begin{array}{c}\text { Places near } \\
\text { Industrial Square } 2\end{array}$ \\
\hline 13 & treatment plant & Much & Day & South to North & 1440 & 3520 & 6720 & 500 & 3000 & $\begin{array}{l}\text { At the beginning of the } \\
\text { industrial city road }\end{array}$ \\
\hline 14 & treatment plant & Low & Day & South to North & 800 & 2400 & 4560 & 60 & 400 & Places near the drainage unit \\
\hline 15 & treatment plant & Much & Night & South to North & 1440 & 3040 & 5440 & 500 & 7900 & $\begin{array}{c}\text { Municipality } \\
\text { Residential Areas }\end{array}$ \\
\hline 16 & treatment plant & Low & Night & South to North & 800 & 2720 & 4800 & 60 & 1500 & $\begin{array}{c}\text { Nearby Places } \\
\text { industrial city road }\end{array}$ \\
\hline
\end{tabular}

7520 meters at night, Therefore, it is recommended to use this software to provide emergency response program and training exercises, but given that in emergencies situations, timing of accidents, speed of operation, and time savings are crucial and very important, Therefore WISER software is able to instantly identify danger areas by selecting chlorine gas, wind direction and leakage (low or high), so that control measures can be taken in critical situations.

\section{Recommendation}

Considering that the most important part of crisis management is providing strategies and opinions when establishing and building high-risk units, Therefore, it is recommended to use the aforementioned software to identify safe areas before construction of chlorination units.

Unfortunately, in recent years, public construction has expanded to the areas surrounding the wells and water resources drainage unit (so called municipal lands), it is suggested that with the supervision of relevant units with Qazvin Governance Crisis Management, First, identify safe locations and then the permit is issued by the municipality. Residents of these areas are also at serious risk if chlorine gas leaks from wells and water and blowing secret wind.

As mentioned, in the area of crisis management, the most important principle is risk prevention. It is hoped that trustee organizations will step in with more vigor and oversight in this area and avoid the traditional thinking of curing the event at the time of the incident.

It is recommended to be used in future studies before identifying high-risk units such as chlorination, using various software to identify safe locations for residential, commercial and industrial construction, and administrative instructions are communicated to the trustee units, and its implementation monitored.

\section{Acknowledgments}

To all the dear colleagues who assisted us in the preparation of this study, We have the ultimate gratitude.

\section{References}

1. Adelfar BA, Farahani Rad R. The Urban Anatomy of Qazvin. Social History Studies. 2012;1(2):51-70.

2. astronomer Y, Muhammad M. Abbasid History (or the Malay Magazine). vahidiya S, editor. Tehran: Vahid; 1987.

3. Qazvini A. Fvaydalsfvyh. Mirahmadi M, editor. Tehran: Scientific; 1990.

4. Qazvini MTV. Khaled Brin (Iran under Shah Safi and Shah Abbas II). Nasiri MR, editor. Tehran: Cultural artifacts Association; 2001.

5. Eleventh Seminar of Probability and Random Processes; September 8 and 9; Imam Khomeini International University, Qazvin.

6. Vaghefi I. Reflecting on the Establishment of Industrial Estates 
in Iran: The Politics of Urban Scale Change.

7. Iran MoIIRo. Qazvin Governorship Statistics and Planning Portal 2014 [

8. Sanai G. Industrial Toxicology. Tehran: University of Tehran; 1997.

9. Yari S, Asadi AF, Normohammadi M. Occupational and Environmental Cancer. Asian Pacific Journal of Environment and Cancer. 2018;1(1).

10. Yari S, Asadi AF, Jarrahi AM, Normohammadi M. CARcinogen EXposure: CAREX. Asian Pacific Journal of Environment and Cancer. 2018;1(1).

11. Grellier J. Comment on "Disinfection Byproducts in Drinking Water and Evaluation of Potential Health Risks of LongTerm Exposure in Nigeria”. Journal of environmental and public health. 2018;2018.

12. Yari S, Fallah AA, Varmazyar S. Assessment of semiquantitative health risks of exposure to harmful chemical agents in the context of carcinogenesis in the latex glove manufacturing industry. Asian Pacific journal of cancer prevention: APJCP. 2015;17(205):11.

13. Morris RD, Audet A-M, Angelillo IF, Chalmers TC, Mosteller F. Chlorination, chlorination by-products, and cancer: a meta-analysis. American journal of public health. 1992;82(7):955-63.

14. Redmill F, Chudleigh M, Catmur J. System safety: HAZOP and software HAZOP: Wiley Chichester; 1999.

15. Adl J, Mohammadfam I, Nezam Aldini Zas. Evaluation Of Chorine Leakage Hazards In Chlorination Stations Of Tehran Water Purification System By Fta Technique. Jundishapur Scientific Medical Journal. 2008;6(4 (55)).

16. Ramabrahmam BV, Swaminathan G. Disaster management plan for chemical process industries. Case study: investigation of release of chlorine to atmosphere. Journal of Loss Prevention in the Process Industries. 2000;13(1):57-62.

17. Tseng J-M, Liu M-Y, Chang R-H, Su J, Shu C-M. Emergency response plan of chlorine gas for process plants in Taiwan. Journal of loss prevention in the process industries. 2008;21(4):393-9.

18. MODEL P-ST. Quest QuarterlyTM.

19. Alley ER. Associate, Inc. 1998. Air Quality Control Handbook.

20. Kumar A. Guidelines for evaluating the characteristics of vapor cloud explosions, flash fires, and bleves. Center for Chemical Process Safety (CCPS) of the AIChE, Published by the American Institute of Chemical Engineers, New York, NY (1994), 387 pages,[ISBN: 0-8169-0474-X], US List Price: \$150. Wiley Online Library; 1996.

21. Zannetti P. Air pollution modeling: theories, computational methods and available software: Springer Science \& Business Media; 2013.

22. Abdolhamidzadeh B, Badri N. Quantitative and qualitative risk assessment in process industries: Andishesara; 2010.

23. Gohararkhi M, Torabi M, Fouad F, Akbari F. Quantitative and qualitative risk assessment in process units, analysis and simulation of network methods, flare with aspen flarenet software: Tash Media Designers Publications; 2009.

24. O’Mahony MT, Doolan D, O'Sullivan A, Hession M. Emergency planning and the Control of Major Accident Hazards (COMAH/Seveso II) Directive: An approach to determine the public safety zone for toxic cloud releases. Journal of hazardous materials. 2008;154(1-3):355-65.

25. Khan FI, Rani JD, Abbasi S. Accident simulation as a tool for assessing and controlling environmental risks in chemical process industries: a case study. Korean Journal of Chemical Engineering. 1998;15(2):124-35.

26. Gangopadhyay R, Das S, Mukherjee M. Chlorine leakage from bonnet of a valve in a bullet - a case study. Journal of loss prevention in the process industries. 2005;18(46):526-30

27. Mortazavi S, Parsarad M, Mahabadi HA, Khavanin A. Evaluation of chlorine dispersion from storage unit in a petrochemical complex to providing an emergency response program. Iran Occupational Health. 2011;8(3).

28. Turkyan A, Islami Z. Engineering of air pollution control: University of Mines and Industries Publications; 2001.

29. Yari S. Inherent safety design in compose of urban gas station. Safety Promotion and Injury Prevention. 2015;3(2):135-40.

30. Yari S. Assessment of potential risk by the failure mode and effects analysis in an air conditioning equipment manufacturing company. Journal of Safety Promotion and Injury Prevention. 2017;5(2).

31. Yari S, Pouyakian M, Jafari MJ, Alipour A, Varmazyar S. Preparation and psychometry of a safety assessment questionnaire for urban gas stations. Safety Promotion and Injury Prevention. 2018;5(3):169-80.

32. M L, A S, D R. Analysis of PHAST and ALOHA Outcome Modeling Software. In: Kimiya HE, editor. First International Conference on Inspection and Safety in Oil and Energy Industries; Tehran2010.

33. M T, S G, A B, A K. Analysis of the aftermath of gas leakage events with ALOHA software: Case study of central warehouse of Yazd National Iranian Oil Products Distribution Company 2014.

34. Medicine USNLo. Welcome to WISER: Wireless Information System for Emergency Responders 2019 [Available from: https://wiser.nlm.nih.gov/.

35. USA Eo. Report on NEWYORK State's Plume Modeling Capabilities2014.

36. Rosenthal I, Kleindorfer PR, Elliott MR. Predicting and confirming the effectiveness of systems for managing lowprobability chemical process risks. Process safety progress. 2006;25(2):135-55.

37. Kwon H-m. The effectiveness of process safety management (PSM) regulation for chemical industry in Korea. Journal of Loss Prevention in the Process Industries. 2006;19(1):13-6.

38. NEWYORK. Center for Chemical Process Safety, Guidelines for Technical Planning for No-Site Emergencies. 2, editor. NEWYORK: AIChe; 1995.

39. Planning MoRaC. Meteorological Organization of the country 2019.

40. Shahidi M, Motevalian M. The Effects Of Chlorine On Cell Cycle And Dna Content Of Wbc In Mice. Razi Journal Of Medical Sciences (Journal Of Iran University Of Medical Sciences). 2005;12(48 (Special Issue)).

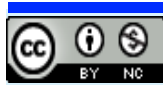

This work is licensed under a Creative Commons AttributionNon Commercial 4.0 International License. 